\title{
Design and validation of a questionnaire to measure the acceptance of telemedicine by healthcare professionals in Germany
}

Martina Verfürth ( $\sim$ martina_verfuerth@yahoo.de)

UCAM Universidad Católica San Antonio de Murcia

Methodology

Keywords: technology acceptance, questionnaire construction, item analysis, physician-patient relationship, trust, interactive eHealth platforms

Posted Date: August 21st, 2020

DOI: https://doi.org/10.21203/rs.3.rs-60425/v1

License: (c) (1) This work is licensed under a Creative Commons Attribution 4.0 International License. Read Full License 


\section{Abstract}

Background: Telemedicine allows healthcare professionals to manage patient treatments remotely and to benefit from the interaction of telemedicine centers. Even though telemedicine responds to the current burdens in healthcare systems, these complex infrastructures depend on technology, financing, organization, policy, legislation, and, not least, on their corresponding acceptance by the user. Little is known in this context about the drivers for this acceptance by healthcare professionals giving treatment. Germany, with the highest healthcare spending in the world, is particularly lagging here.

Methods: A literature review was conducted to identify the acceptance factors that had already been detected and frequently confirmed. These factors were evaluated according to the coverage of the interactive infrastructures with telemedicine centers and how accurately they fitted Germany. The identified factors were adapted, and missing factors were designed, via an idea collection for items. The reliability of the developed constructs was tested using a field test to check the constructs using item revision analysis.

Results: Frequently supported external variables, taken from 17 filtered studies covering the technical, organizational, social, legal, and individual context, were identified. However, the review showed that there was less focus on the German setting and the interactive aspect, so the market-related variables were adapted and new constructs of "trust in the telemedicine center" and "relationship to patient" were added. Ten variables were proven to have a reliability, measured with Cronbach's Alpha, of more than 0.7.

Conclusion: This paper enhances the already existing technology acceptance studies in healthcare by covering German specifications and the interactive character of TSSs. A corresponding questionnaire has been developed ready for future research.

\section{Background}

Several societal developments make it likely that telemedicine will be an important future solution in healthcare. In particular, this potential has been enhanced by the current Sars-CoV2 pandemic, since telemedicine allows physicians to make contact with their patients while reducing face-to-face contact and controlling virus transfer $[1,2,3]$. Telemedicine in rural medical care and for the monitoring of the growing numbers of chronically sick persons can be an answer to the lack of medical specialists in the countryside, the demographically triggered aging population, and the increase in chronic diseases [4]. Several studies discuss the controversies in the effectiveness of telemedicine $[5,6]$. However, the significant potential for improving the quality of life for patients can clearly be seen [7]. For this reason, this paper focuses on Germany; on the one hand, Germany is a strongly industrialized and innovative nation but, on the other, it still faces challenges in terms of digitalization and eHealth, with a gradient from East to West Germany as well as rural and urban differences. Looking at the healthcare system in Germany, healthcare spending is the highest in Europe but, on the other hand, there is a lack of specialists and there is high mortality due to behavioral and lifestyle-influenced risks [7,8]. Looking specifically at telemedicine, Germany has seen the advantages in different past projects: for example, a reduction of the frequency of adverse events and an increase in treatment safety in cardiology and intensive and emergency care [4]. However, there are many barriers hindering full integration in the German healthcare systems, not least because of the complexity of the extensive and detailed healthcare sector. The main obstacles are unanswered issues regarding draft laws and legislation $[9,10,11,12]$ in terms of the financing of the different services and tasks in telemedicine, IT security, and data access, as well as transparency, the enhancement of medical guidelines with digital aspects, responsibilities for the development of innovation, and the legal responsibilities of healthcare professionals (HCPs) [13]. There is no nationwide telemedicine infrastructure in Germany, and the current implementation of telemedicine shows several isolated single solutions limited by time, region, and financial support from insurance companies and industry [14].

Alongside systems and services maintained by hospitals or doctor's offices, solutions that are integrated with telemedicine centers are conceivable [14]. This structure for the involvement of telemedicine centers is the focus of the research in this study, which concentrates on telemonitoring care in Germany. The starting point is a potential telemonitoring service system (TSS). Telemedicine means a healthcare service provided at distance using information and communication technology (ICT). Telemonitoring is defined as the control of a patient by the treating physician and a telemedicine center. The parameters that are relevant indicators are measured constantly and transferred to the center to be recorded and analyzed for diagnosis, treatment and prevention [15,16]. This system only works with patients who are remote from the physician as well as from the healthcare professionals in their interaction with the telemedicine center. In this article, interaction means the communication with the system by the patient himself, the treating physician or therapist, and the healthcare professional working in the telemedicine center as a service provider. Here, an interaction platform is defined by Ihlenburg [17] as a restricted, virtual, internetbased room offering all participants different services so that they can exchange targeted and suitable information for location- and time-independent communication. In this working scheme, acceptance by the healthcare professionals is an essential factor in the implementation of a successful program [18]

\section{Theoretical foundations: Measurement of technology acceptance and transfer to medicine}

In the literature there are many, mostly interdisciplinary, approaches to defining the term "acceptance". Overall, there is a consensus that acceptance has different dimensions, including attitude and behavioral results $[19,20,21,22]$. Acceptance presents a latent construct, meaning that it cannot be measured directly and needs to be operationalized. Acceptance models describe concepts that try to shape which determinants influence acceptance and which elements are the constituents of acceptance [23]. Technology acceptance characterizes the individual's voluntary and intentional adoption of the technology [24]. Technology acceptance research is a broad field and looks at the area of information systems. The gold standard for evaluating technology acceptance is the technology acceptance model (TAM) of Davis [23]. Davis claimed that the factors perceived usefulness (PU) and perceived ease of use (PEOU) determine attitude, and that this again influences behavioral intention (BI). Further, PEOU affects PU, and PU independently affects BI [24]. The term BI describes what leads to actual use and can be understood to account for acceptance [24]. Later, during the evolution of the TAM, the model was extended in TAM 2, which removed attitude but added a variable covering social influence, with the factor known as subjective norms (SN) that directly influences PU and 
BI $[25,26,27,28]$ Venkatesh et al. [28] later investigated the unification of acceptance studies and developed the Unified Theory of Acceptance and Use of Technology (UTAUT). The most critical step was adding the facilitating conditions coming from the general research into IT acceptance as one determinant of $\mathrm{BI}[26,29]$. The TAM has reached the gold standard, as reviews of this widely-used model have shown that the TAM is a reliable model for analyzing acceptance by individuals $[25,26,30]$, not least because of its simplicity and clarity $[31,32,33]$. However, several revisions to the TAM have been proposed, and the model has been questioned; in addition, many other determinants influencing the core constructs have been tested in the past [26]. It is certainly the case that the results for the factors, relationships and effects differ by system types and users [31,34]. Looking at healthcare technology, the TAM has been the most commonly used model to study acceptance $[18,35]$ and validated through questionnaires that are able to explain the reasons why a particular technology is used [36].

\section{Methods}

For the questionnaire construction, a literature review was conducted to collect the factors that build and influence acceptance. A frequency analysis identified the most common confirmed factors, and these were then clustered. After reviewing the content of the factor clusters, an item collection was performed to adapt and build the constructs for the German interactive healthcare context. The constructs were operationalized in statements, and the questionnaire was formed. A test of the questionnaire was conducted, and an item revision analysis checked the reliability of the constructs.

Literature search strategy

A manual literature review was performed to capture the constructs to explain the factors influencing acceptance of an interactive telemedicine structure and to check the existing studies on technology acceptance of the German healthcare system. International studies published between January 2000 and January 2020 were selected from PubMed by keywords. To ensure that the papers were of high quality, only studies that had been peer-reviewed were included. The search keywords were telemedicine OR telehealth AND technology acceptance model. Studies in languages other than German and English, as well as studies that did not have open access or full text availability, were not included. The review approach and findings are illustrated in Fig. 1, which follows the PRISMA guidelines for reviews [37].

\section{Study exclusion criteria for the literature review}

The following exclusions were made to produce a clear filtered pool of factors. After manually reviewing the clinical trials, qualitative research (e.g. interviews, pure literature reviews, and research on technology assessment (e.g. effectiveness and feasibility)) was excluded. Analyses of patient acceptance or acceptance by other non-healthcare target groups were not considered. Most importantly, research on the assessment of healthcare IT and on programs without interactive telemedicine aspects (by which we mean communication with a telemedicine center and/or the patient) such as documentation software, single devices, electronical patient records or general technology or information technology, was taken out. Only studies that used the TAM, UTAUT or the extension variables were considered, to remain with the core constructs and make a similar basis for the item creation, to ensure compatibility. Moderating factors, especially in terms of socio-demographics, were excluded. Out of 253 records, 17 studies were filtered out and passed the eligibility test.

Figure 1: Flow chart to show the selection criteria for the systematic literature review

\section{Frequency analysis and clustering of acceptance factors for studies in the review}

Fifty-eight different construct relationships could be identified in these 17 studies $[34,38,39,40,41,42,43,44,45,46,47,48,49,50,51,52,53,54]$ Only those constructs that were supported more than twice in a construct relationship were picked out. Clearly, the review shows that the core constructs from the original models, like behavioral intention (BI), impacted by attitude (ATT), and influenced by perceived ease of use (PEOU) and perceived usefulness (PU), were also identified in these studies as essential variables. Further analysis of the external variables showed that they can be clustered into five contexts [55], as set out below.

The technological context explains the handling of the system, including PEOU, and the performance impact, including PU. Next, the organizational context is covered by the facilitator variable, which describes whether there are suitable resources and a suitable environment for the clinical task and the system implementation, as well as the compatibility variable, which describes the fit to the current tasks. The facilitator factor is influenced on the behavioral level by the variable of perceived behavioral control, and these can be merged. The individual context describes the confidence and competence in handling a system, using the variable habit (HAB). The social context is covered by the subjective norms (SN) variable, which describes the influence on the user of other people. Another finding is the influence of market-related factors. The review showed that there were economic variables that were focused on financing, such as rewards in terms of financial support or compensation for medical fees [38,39,42]. Another market factor is the regulatory or legal context. In this area the perceived importance of data security (IOD) stands out as an influence on the behavioral intention $[40,45,48]$. However, for a comprehensive review there were several gaps. First, a view on the interaction framework and the service context variables was missing. Secondly, investigations focusing on the German market were absent. Therefore, the variables needed to be analyzed and equivalent indicator dimensions built. It was necessary to build the missing dimensions by an idea collection of items. A sufficient item pool for each construct was created. Table 1 shows the origin of the items and the definition of each construct, as derived from the analyzed studies. 
Table 1

Results of operationalization: Construct definitions and scales of item dimensions

\begin{tabular}{|c|c|c|c|c|c|}
\hline Construct & Definition & Item & $\begin{array}{l}\text { Dimensions of } \\
\text { added items } \\
\text { from idea } \\
\text { collection }\end{array}$ & $\begin{array}{l}\text { Items and their } \\
\text { operationalization in a } \\
\text { questionnaire }\end{array}$ & $\begin{array}{l}\text { Origin of } \\
\text { idea for } \\
\text { statement }\end{array}$ \\
\hline \multirow[t]{4}{*}{ Attitude } & \multirow{4}{*}{$\begin{array}{l}\text { The HCP's individual positive or negative feelings about } \\
\text { using TSS [73]. }\end{array}$} & ATT1 & & I think positively about TSS. & [73] \\
\hline & & ATT2 & & $\begin{array}{l}\text { Using TSS in patient care and } \\
\text { management is a good idea. }\end{array}$ & [73] \\
\hline & & ATT3 & $\begin{array}{l}\text { General } \\
\text { attitude to } \\
\text { telemedicine }\end{array}$ & $\begin{array}{l}\text { I endorse the establishment } \\
\text { and expansion of } \\
\text { telemedicine systems. }\end{array}$ & $\begin{array}{l}\text { Idea } \\
\text { collection } \\
\text { of present } \\
\text { study }\end{array}$ \\
\hline & & ATT4 & $\begin{array}{l}\text { General } \\
\text { attitude to } \\
\text { digitalization }\end{array}$ & $\begin{array}{l}\text { Digitalization is an important } \\
\text { topic for patient treatment in } \\
\text { future. }\end{array}$ & $\begin{array}{l}\text { Idea } \\
\text { collection } \\
\text { of present } \\
\text { study }\end{array}$ \\
\hline \multirow[t]{5}{*}{$\begin{array}{l}\text { Behavioral } \\
\text { Intention }\end{array}$} & \multirow[t]{5}{*}{ The HCP's willingness to use the system [27]. } & Bl1 & & $\begin{array}{l}\text { Assuming I have access to } \\
\text { TSS, }\end{array}$ & {$[28,74]$} \\
\hline & & & & I intend to use it. & \\
\hline & & $\mathrm{BI} 2$ & & I intend to use TSS regularly. & {$[24,74]$} \\
\hline & & $\mathrm{BI} 3$ & & $\begin{array}{l}\text { I consider referring my clients } \\
\text { to TSS. }\end{array}$ & [34] \\
\hline & & $\mathrm{B} \mid 4$ & & $\begin{array}{l}\text { I actively integrate TSS in my } \\
\text { patient care. }\end{array}$ & [74] \\
\hline \multirow[t]{6}{*}{$\begin{array}{l}\text { Perceived } \\
\text { Usefulness }\end{array}$} & \multirow[t]{6}{*}{$\begin{array}{l}\text { The degree to which the HCP believes using TSS would } \\
\text { enhance his / her patient care and management } \\
\text { (performance/service) [75]. }\end{array}$} & PU1 & & $\begin{array}{l}\text { Using TSS in my job enables } \\
\text { me to accomplish tasks more } \\
\text { quickly. }\end{array}$ & [24] \\
\hline & & PU2 & & $\begin{array}{l}\text { Using TSS improves my } \\
\text { patient care and } \\
\text { management. }\end{array}$ & {$[27,74]$} \\
\hline & & PU3 & & $\begin{array}{l}\text { Using TSS in my job } \\
\text { increases my productivity. }\end{array}$ & {$[27,74,76]$} \\
\hline & & PU4 & & $\begin{array}{l}\text { Using TSS in my job } \\
\text { enhances my effectiveness } \\
\text { on the job. }\end{array}$ & {$[27,74,76]$} \\
\hline & & PU5 & & $\begin{array}{l}\text { Using TSS makes it easier to } \\
\text { do my job. }\end{array}$ & [76] \\
\hline & & PU6 & & I find TSS useful in my job. & {$[27,74,76]$} \\
\hline \multirow[t]{5}{*}{$\begin{array}{l}\text { Perceived Ease } \\
\text { of Use }\end{array}$} & \multirow[t]{5}{*}{$\begin{array}{l}\text { The degree to which the HCP believes that using TSS is } \\
\text { free of efforts / TSS is difficult to use }[34,75] \text {. }\end{array}$} & PEOU1 & & $\begin{array}{l}\text { Learning to operate TSS is } \\
\text { easy for me. }\end{array}$ & [76] \\
\hline & & PEOU2 & & I find TSS easy to use. & {$[27,74,76]$} \\
\hline & & PEOU3 & & $\begin{array}{l}\text { I think using TSS is easy for } \\
\text { my patients. }\end{array}$ & [76] \\
\hline & & PEOU4 & & $\begin{array}{l}\text { I find TSS to be flexible when } \\
\text { I interact with it. }\end{array}$ & [76] \\
\hline & & PEOU5 & & $\begin{array}{l}\text { My interaction with TSS is } \\
\text { clear and understandable. }\end{array}$ & {$[27,74,76]$} \\
\hline \multirow[t]{4}{*}{ Facilitators } & \multirow{4}{*}{$\begin{array}{l}\text { The degree to which the HCP believes that organizational } \\
\text { and technical resources and environment exist to support } \\
\text { the implementation and use of the system }[28,74] \text {. }\end{array}$} & FAC1 & & $\begin{array}{l}\text { I have the necessary } \\
\text { resources to use the system. }\end{array}$ & [74] \\
\hline & & FAC2 & & $\begin{array}{l}\text { I will use TSS if I receive } \\
\text { appropriate training. }\end{array}$ & [45] \\
\hline & & FAC3 & & $\begin{array}{l}\text { I will use TSS if I receive the } \\
\text { necessary technical } \\
\text { assistance. }\end{array}$ & [45] \\
\hline & & FAC4 & & $\begin{array}{l}\text { Given the resources, } \\
\text { opportunities and knowledge } \\
\text { it takes to use the system, it } \\
\text { is easy for me to use the } \\
\text { system. }\end{array}$ & [74] \\
\hline
\end{tabular}

Abbreviations: ATT $=$ Attitude, $\mathrm{BI}=$ Behavioral Intention, $\mathrm{COMP}=$ Compatibility, $\mathrm{FAC}=$ Facilitators, $\mathrm{HAB}=\mathrm{Habit}, \mathrm{IOD}=\mathrm{Importance}$ of $\mathrm{Data}$ Security, $\mathrm{PEOU}=$ Perceived Ease of Use, PU = Perceived Usefulness, REL = Relationship to patient, SN = Subjective norms, TRU = Trust in Telemedicine Center 


\begin{tabular}{|c|c|c|c|c|c|}
\hline Construct & Definition & Item & $\begin{array}{l}\text { Dimensions of } \\
\text { added items } \\
\text { from idea } \\
\text { collection }\end{array}$ & $\begin{array}{l}\text { Items and their } \\
\text { operationalization in a } \\
\text { questionnaire }\end{array}$ & $\begin{array}{l}\text { Origin of } \\
\text { idea for } \\
\text { statement }\end{array}$ \\
\hline \multirow[t]{5}{*}{ Compatibility } & \multirow{5}{*}{$\begin{array}{l}\text { The degree to which TSS is perceived as being consistent } \\
\text { with the existing needs, values and past experiences of } \\
\text { the HCP, who is a potential adopter of the system [76]. }\end{array}$} & COMP1 & & $\begin{array}{l}\text { Using the TSS is compatible } \\
\text { with all aspects of my work. }\end{array}$ & [28] \\
\hline & & COMP2 & & $\begin{array}{l}\text { I think that using the system } \\
\text { fits well with the way I like to } \\
\text { work. }\end{array}$ & [28] \\
\hline & & СOMP3 & & $\begin{array}{l}\text { Using the system fits into my } \\
\text { work style. }\end{array}$ & [28] \\
\hline & & COMP4 & & $\begin{array}{l}\text { The use of TSS implies major } \\
\text { changes in my clinical } \\
\text { practice. }\end{array}$ & $\begin{array}{l}{[41,45,} \\
50]\end{array}$ \\
\hline & & COMP5 & & $\begin{array}{l}\text { The use of TSS promotes my } \\
\text { clinical practice. }\end{array}$ & {$[50]$} \\
\hline \multirow[t]{4}{*}{$\begin{array}{l}\text { Subjective } \\
\text { Norms }\end{array}$} & \multirow[t]{4}{*}{$\begin{array}{l}\text { The HCP's perception that most people who are important } \\
\text { to him / her think he / she should or should not perform } \\
\text { the behavior in question [73]. }\end{array}$} & SN1 & & $\begin{array}{l}\text { People who influence my } \\
\text { behavior think that I should } \\
\text { use the system. }\end{array}$ & {$[27,74]$} \\
\hline & & SN2 & & $\begin{array}{l}\text { People who are important to } \\
\text { me think that I should use the } \\
\text { system. }\end{array}$ & {$[27,74]$} \\
\hline & & SN3 & & $\begin{array}{l}\text { Patients welcome me using } \\
\text { TSS. }\end{array}$ & {$[50]$} \\
\hline & & SN4 & & $\begin{array}{l}\text { Other colleagues welcome } \\
\text { me using TSS. }\end{array}$ & [50] \\
\hline \multirow[t]{4}{*}{ Habit } & \multirow[t]{4}{*}{$\begin{array}{l}\text { Degree of IT affinity and perceived competence according } \\
\text { to the routine handling of IT }[45,47] \text {. }\end{array}$} & HAB1 & & $\begin{array}{l}\text { I have used telemedicine in } \\
\text { the past. }\end{array}$ & [45] \\
\hline & & HAB2 & & $\begin{array}{l}\text { I already use telemedicine } \\
\text { technologies. }\end{array}$ & [45] \\
\hline & & HAB3 & & $\begin{array}{l}\text { I feel comfortable with } \\
\text { information and } \\
\text { communication technology. }\end{array}$ & {$[45,47]$} \\
\hline & & HAB4 & & $\begin{array}{l}\text { I feel comfortable with using } \\
\text { and consulting technology } \\
\text { for my patients in my daily } \\
\text { business. }\end{array}$ & {$[45,47]$} \\
\hline \multirow[t]{5}{*}{$\begin{array}{l}\text { Importance of } \\
\text { Data Security }\end{array}$} & \multirow[t]{5}{*}{$\begin{array}{l}\text { Degree of perceived importance of security of patient data } \\
\text { without loss of therapy quality, of ethical considerations } \\
\text { and of transparency of information [45]. }\end{array}$} & IOD1 & & $\begin{array}{l}\text { Technical standards for the } \\
\text { handling of patients' medical } \\
\text { data are necessary. }\end{array}$ & [40] \\
\hline & & IOD2 & & $\begin{array}{l}\text { Committing to standards for } \\
\text { the handling of patients' } \\
\text { medical data is necessary for } \\
\text { my practice. }\end{array}$ & {$[40]$} \\
\hline & & IOD3 & & $\begin{array}{l}\text { It is important to me to be } \\
\text { able to inform my patients in } \\
\text { detail about the use of their } \\
\text { medical data. }\end{array}$ & [40] \\
\hline & & IOD4 & $\begin{array}{l}\text { Digital } \\
\text { treatment } \\
\text { quality }\end{array}$ & $\begin{array}{l}\text { Quality definitions need to be } \\
\text { transferred from the analog } \\
\text { treatment into the digital } \\
\text { world. }\end{array}$ & $\begin{array}{l}\text { Idea } \\
\text { collection }\end{array}$ \\
\hline & & IOD5 & $\begin{array}{l}\text { Legal, ethical } \\
\text { and scientifical } \\
\text { framework }\end{array}$ & $\begin{array}{l}\text { Expert associations must } \\
\text { consider legal and ethical } \\
\text { questions when it comes to } \\
\text { data security, and clarify the } \\
\text { usage of data for research. }\end{array}$ & $\begin{array}{l}\text { Idea } \\
\text { collection }\end{array}$ \\
\hline \multirow[t]{2}{*}{ Financing } & \multirow[t]{2}{*}{$\begin{array}{l}\text { Degree of monetary motivation and attitude to the } \\
\text { responsibility of financing of TSS in the healthcare } \\
\text { systems for patients }[38,39,42] \text {. }\end{array}$} & FIN1 & & $\begin{array}{l}\text { Incentives for physicians } \\
\text { need to be offered for } \\
\text { continuous and frequent use. }\end{array}$ & [42] \\
\hline & & FIN2 & Bonus & $\begin{array}{l}\text { I should get additionally } \\
\text { rewarded for using TSS. }\end{array}$ & [42] \\
\hline
\end{tabular}

Abbreviations: ATT $=$ Attitude, $\mathrm{BI}=$ Behavioral Intention, $\mathrm{COMP}=$ Compatibility, $\mathrm{FAC}=$ Facilitators, $\mathrm{HAB}=\mathrm{Habit}, \mathrm{IOD}=\mathrm{Importance}$ of $\mathrm{Data}$ Security, $\mathrm{PEOU}=$ Perceived Ease of Use, PU = Perceived Usefulness, REL = Relationship to patient, SN = Subjective norms, TRU = Trust in Telemedicine Center 


\begin{tabular}{|c|c|c|c|c|c|}
\hline Construct & Definition & Item & $\begin{array}{l}\text { Dimensions of } \\
\text { added items } \\
\text { from idea } \\
\text { collection }\end{array}$ & $\begin{array}{l}\text { Items and their } \\
\text { operationalization in a } \\
\text { questionnaire }\end{array}$ & $\begin{array}{l}\text { Origin of } \\
\text { idea for } \\
\text { statement }\end{array}$ \\
\hline & & FIN3 & $\begin{array}{l}\text { Financial } \\
\text { evaluation of } \\
\text { digital service }\end{array}$ & $\begin{array}{l}\text { Digital services via TSS must } \\
\text { be evaluated and paid for } \\
\text { differently from the analog } \\
\text { service. }\end{array}$ & $\begin{array}{l}\text { Idea } \\
\text { collection }\end{array}$ \\
\hline & & FIN4 & Funding & $\begin{array}{l}\text { The usage of TSS is } \\
\text { particularly worthy of support } \\
\text { in regards to funding. }\end{array}$ & $\begin{array}{l}\text { Idea } \\
\text { collection }\end{array}$ \\
\hline & & FIN5 & Reimbursement & $\begin{array}{l}\text { It is important that the cost of } \\
\text { TSS is reimbursed for my } \\
\text { patients. }\end{array}$ & $\begin{array}{l}\text { Idea } \\
\text { collection }\end{array}$ \\
\hline & & FIN6 & $\begin{array}{l}\text { Standard } \\
\text { financing }\end{array}$ & $\begin{array}{l}\text { TSS needs to be managed } \\
\text { with a selective agreement } \\
\text { (non-standard care). }\end{array}$ & $\begin{array}{l}\text { Idea } \\
\text { collection }\end{array}$ \\
\hline & & FIN7 & $\begin{array}{l}\text { Private } \\
\text { payment }\end{array}$ & $\begin{array}{l}\text { It is acceptable for patients to } \\
\text { pay for the service privately. }\end{array}$ & $\begin{array}{l}\text { Idea } \\
\text { collection }\end{array}$ \\
\hline & & FIN8 & Incentives & $\begin{array}{l}\text { Whether TSS is paid for } \\
\text { privately or is reimbursed via } \\
\text { insurance should depend on } \\
\text { the treatment. }\end{array}$ & $\begin{array}{l}\text { Idea } \\
\text { collection }\end{array}$ \\
\hline & & FIN9 & Investment & $\begin{array}{l}\text { For additional services, the } \\
\text { cost of the initial equipment } \\
\text { should be paid for as an } \\
\text { investment by the doctor's } \\
\text { office. }\end{array}$ & $\begin{array}{l}\text { Idea } \\
\text { collection }\end{array}$ \\
\hline \multirow[t]{4}{*}{$\begin{array}{l}\text { Importance of } \\
\text { Standardization }\end{array}$} & \multirow[t]{4}{*}{$\begin{array}{l}\text { Degree of perceived importance of conducting and } \\
\text { recording the treatment in a standardized way without } \\
\text { loss of quality [40]. }\end{array}$} & STAN1 & & $\begin{array}{l}\text { I am in favor of standardized } \\
\text { documentation for medical } \\
\text { practices. }\end{array}$ & [40] \\
\hline & & STAN2 & & $\begin{array}{l}\text { In the case of standardized } \\
\text { treatment processes, the } \\
\text { administrative effort exceeds } \\
\text { the medical benefits. }\end{array}$ & [40] \\
\hline & & STAN3 & & $\begin{array}{l}\text { Daily work in medical } \\
\text { practice is too heterogeneous } \\
\text { for important processes to be } \\
\text { standardized. }\end{array}$ & [40] \\
\hline & & STAN4 & Evidence basis & $\begin{array}{l}\text { The TSS needs to analyze } \\
\text { data based on the evidence } \\
\text { and to show that } \\
\text { transparently. }\end{array}$ & $\begin{array}{l}\text { Idea } \\
\text { collection }\end{array}$ \\
\hline \multirow[t]{6}{*}{$\begin{array}{l}\text { Relationship to } \\
\text { Patient }\end{array}$} & \multirow[t]{6}{*}{$\begin{array}{l}\text { Degree of fear of losing contact and relationship with the } \\
\text { patient because of changes in the means of } \\
\text { communication and involvement of telemedicine experts. }\end{array}$} & REL1 & Loss of patient & $\begin{array}{l}\text { I fear losing patients as a } \\
\text { result of TSS, because they } \\
\text { will not need me anymore. }\end{array}$ & $\begin{array}{l}\text { Idea } \\
\text { collection }\end{array}$ \\
\hline & & REL2 & $\begin{array}{l}\text { Shift of } \\
\text { reference point } \\
\text { / contact loss }\end{array}$ & $\begin{array}{l}\text { With TSS my patients need } \\
\text { less help, because many } \\
\text { things can be clarified with } \\
\text { the center. }\end{array}$ & $\begin{array}{l}\text { Idea } \\
\text { collection }\end{array}$ \\
\hline & & REL3 & $\begin{array}{l}\text { Loss of } \\
\text { treatment path }\end{array}$ & $\begin{array}{l}\text { I fear losing control over the } \\
\text { treatment pathway, because I } \\
\text { will not be the first to be } \\
\text { involved anymore. }\end{array}$ & $\begin{array}{l}\text { Idea } \\
\text { collection }\end{array}$ \\
\hline & & REL4 & $\begin{array}{l}\text { Intensity of } \\
\text { patient } \\
\text { relationship }\end{array}$ & $\begin{array}{l}\text { The relationship with my } \\
\text { patients will be more } \\
\text { intensive because of the } \\
\text { extensive support. }\end{array}$ & $\begin{array}{l}\text { Idea } \\
\text { collection }\end{array}$ \\
\hline & & REL5 & $\begin{array}{l}\text { Treatment } \\
\text { mixture } \\
\text { effect }\end{array}$ & $\begin{array}{l}\text { The treatment mix of analog } \\
\text { and digital will strengthen the } \\
\text { patient-physician } \\
\text { relationship. }\end{array}$ & $\begin{array}{l}\text { Idea } \\
\text { collection }\end{array}$ \\
\hline & & REL6 & Compliance & $\begin{array}{l}\text { The treatment adherence of } \\
\text { my patients will increase. }\end{array}$ & $\begin{array}{l}\text { Idea } \\
\text { collection }\end{array}$ \\
\hline
\end{tabular}

Abbreviations: $\mathrm{ATT}=$ Attitude, $\mathrm{BI}=$ Behavioral Intention, $\mathrm{COMP}=$ Compatibility, $\mathrm{FAC}=$ Facilitators, $\mathrm{HAB}=\mathrm{Habit}, \mathrm{IOD}=\mathrm{Importance}$ of $\mathrm{Data}$ Security, $\mathrm{PEOU}=$ Perceived Ease of Use, PU = Perceived Usefulness, REL = Relationship to patient, SN = Subjective norms, TRU = Trust in Telemedicine Center 


\begin{tabular}{|c|c|c|c|c|c|}
\hline Construct & Definition & Item & $\begin{array}{l}\text { Dimensions of } \\
\text { added items } \\
\text { from idea } \\
\text { collection }\end{array}$ & $\begin{array}{l}\text { Items and their } \\
\text { operationalization in a } \\
\text { questionnaire }\end{array}$ & $\begin{array}{l}\text { Origin of } \\
\text { idea for } \\
\text { statement }\end{array}$ \\
\hline & & REL7 & $\begin{array}{l}\text { Accessibility of } \\
\text { patients }\end{array}$ & $\begin{array}{l}\text { With TSS I will have better } \\
\text { contact with all my patients, } \\
\text { no matter how far away they } \\
\text { are. }\end{array}$ & $\begin{array}{l}\text { Idea } \\
\text { collection }\end{array}$ \\
\hline & & REL8 & $\begin{array}{l}\text { Reachability of } \\
\text { patients }\end{array}$ & $\begin{array}{l}\text { I will have a better connection } \\
\text { to patients who visit me } \\
\text { rarely. }\end{array}$ & $\begin{array}{l}\text { Idea } \\
\text { collection }\end{array}$ \\
\hline \multirow{8}{*}{$\begin{array}{l}\text { Trust in } \\
\text { Telemedicine } \\
\text { Center }\end{array}$} & \multirow{8}{*}{$\begin{array}{l}\text { Degree of personal trust in the contact person at the } \\
\text { telemedicine center as well as organizational trust that } \\
\text { the center itself will treat the HCP's patients as required } \\
\text { and in accordance with the standards }[66,67]\end{array}$} & TRU1 & General trust & $\begin{array}{l}\text { Generally, I can trust other } \\
\text { people. }\end{array}$ & [67] \\
\hline & & TRU2 & $\begin{array}{l}\text { Certification of } \\
\text { service center }\end{array}$ & $\begin{array}{l}\text { I trust a certified service } \\
\text { center that consults my } \\
\text { patients. }\end{array}$ & $\begin{array}{l}\text { Idea } \\
\text { collection }\end{array}$ \\
\hline & & TRU3 & $\begin{array}{l}\text { Trust in other } \\
\text { HCPs }\end{array}$ & $\begin{array}{l}\text { I feel good about patients } \\
\text { being monitored / treated by } \\
\text { another therapist / physician. }\end{array}$ & $\begin{array}{l}\text { Idea } \\
\text { collection }\end{array}$ \\
\hline & & TRU4 & $\begin{array}{l}\text { Constancy in } \\
\text { contact }\end{array}$ & $\begin{array}{l}\text { It is important to me to have } \\
\text { a fixed contact person at the } \\
\text { center. }\end{array}$ & $\begin{array}{l}\text { Idea } \\
\text { collection }\end{array}$ \\
\hline & & TRU5 & $\begin{array}{l}\text { Personal } \\
\text { contact }\end{array}$ & $\begin{array}{l}\text { It is important to me to have } \\
\text { personal contact with the } \\
\text { experts providing the } \\
\text { treatment, in advance. }\end{array}$ & $\begin{array}{l}\text { Idea } \\
\text { collection }\end{array}$ \\
\hline & & TRU6 & $\begin{array}{l}\text { Loss of } \\
\text { treatment } \\
\text { control }\end{array}$ & $\begin{array}{l}\text { I fear that a colleague would } \\
\text { treat a patient differently. }\end{array}$ & $\begin{array}{l}\text { Idea } \\
\text { collection }\end{array}$ \\
\hline & & TRU7 & $\begin{array}{l}\text { Information } \\
\text { asymmetry }\end{array}$ & $\begin{array}{l}\text { I fear that I will not be able to } \\
\text { provide all the information to } \\
\text { my patient in time. }\end{array}$ & $\begin{array}{l}\text { Idea } \\
\text { collection }\end{array}$ \\
\hline & & TRU8 & $\begin{array}{l}\text { Standard } \\
\text { processes }\end{array}$ & $\begin{array}{l}\text { I like to be informed } \\
\text { beforehand about standard } \\
\text { processes and algorithms. }\end{array}$ & $\begin{array}{l}\text { Idea } \\
\text { collection }\end{array}$ \\
\hline
\end{tabular}

\section{Adapting variables in the context of the German healthcare environment}

Diseases like cardiovascular disorders (which take the biggest share of medical expenses and have the highest mortality) and pulmonary disease, as well as diabetes (which has the highest increase in prevalence) impact heavily on the German healthcare system [56,57]. Thus, a crucial influence when choosing the relevant item dimensions to fit the German context were the statements on telemedicine and digitalization made by the German diabetes association (DDG) [58], the German association of cardiology (DGK) [14], and the German association of pneumology (DGP) [59]. These position papers are addressed to the political situation and are considered in the legislative procedure. All the parties involved are working intensively on telemedicine topics.

Taking these statements into account, a call for clarity on the financing of treatments was noted throughout $[14,58,59,60]$. For this reason, the ideas of Hwang et al. (2014) were extended by further items. It was assumed that the financial evaluation of a digital service compared to an analog service (see item FIN3) is an influencing factor (Ickarth 2018). Specific to German healthcare is the question of including the service in the standard financing of care (see item FIN6). The payment scheme (see item FIN5) for patients is also unclear: the scheme needs either to be paid for privately (see item FIN7) or to be covered by reimbursement from insurance (see item FIN8) [61]. Lastly, the funding (see item FIN4) for the specific cost of implementation in a medical facility (see item FIN9) could possibly be an influencing factor [58]. One other field for action mentioned in those position papers is the importance of developing digital standards to ensure high-quality patient care $[14,58,59,60]$. The items concerning the importance of standardization were oriented using the ideas of Dünnebeil et al. [40]. One item regarding the development of evidence-based standards (see item STAN4) was added. Along with the requirements for technical standards and for transparency towards patients in relation to data handling, the mandatory adherence to the principles of data management was consistently mentioned. In this context two other items were added to the section on the importance of data security, to cover assurance of the treatment quality (see item IOD3) in the digital environment and the responsibility of associations to discuss the legal, ethical and scientifical framework for the data (see item IOD4) in such service systems [58].

\section{Adding new variables in the context of the interactive telemedicine structure}

When it comes to an interactive system, with the patient and the healthcare professionals in the telemedicine center as additional players, fewer studies have concentrated on this new mode of communication, which might be a determinant of the behavioral intention of a physician. On the one side, the change in communication might mean that the relationship to the patient changes and the responsibilities for the treatment decisions and pathway need to be adapted. This becomes important because patients become better informed and the physician-patient relationship changes accordingly [58]. On the other side, new methods of communication with medical colleagues in the telemedicine center can be seen. Looking into the literature, aspects of this digital collaboration 
emerge that are similar to those for eConsult platforms (exchange of knowledge about patient cases between HCPs via a digital platform). These aspects were considered for the development of this dimension [62,63]. When dealing with interactions between people, trust is an important form of social capital $[64,65,66]$. Consequently, two new constructs - "relationship to patient" and "trust in the telemedicine center" - were built. It is assumed that the perceived change in the patient relationship is determined either by the fear of losing the patient and losing control of the clinical treatment pathway (see items REL 1 and REL3) because of the involvement of another healthcare professional at the center (see item REL2), or by the hope of strengthening the patient relationship (see item REL4) because of increasing contact points in the mixed analog and digital communication (see item REL5). The quick monitoring of inaccessible (see item REL7) and immobile patients (see item REL8) can be seen as an advantage for the patient-physician relationship. The goal would be to increase the treatment adherence (compliance) of a patient (see item REL6) [58,62].

Trust in the telemedicine center is assumed to be regulated by general trust (see item TRU1), following the model originally proposed by Yamagashi and Yamagashi [67]. Trust can also be created by certification (see item TRU2) and standard processes (see item TRU8), as well as by fixed and stable personal contacts (see item TRU4) with the HCPs involved (see item TRU5), which can be described as institutional trust (see item TRU3) [65]. Also, distrust can appear when there is the fear of losing control of the treatment (see item TRU6) or of not getting sufficient information when passing on responsibility to colleagues (see item TRU7) [62,63].

Thus, for the completely new variables TRU and REL, more than eight items were developed in order to produce a set that could undergo item revision after the field testing. The operationalization was framed by the wordings from the original TAMs that had already been established and validated, and from the most commonly used scales in the reviewed studies, to pick out formulations for the medical context [68]. A minimum of four items were defined as the indicators for each construct. The construct for attitude was therefore extended to cover the aspects of the generic attitudes to general telemedicine (see item ATT3) and digitalization (see item ATT4).

The corresponding statements were then translated into German (see Additional File 1). The field test assessed possible distortions or difficulties in comprehension, and the German wording for BI, PEOU, PU and SN was aligned with the corresponding proposals [69]. The participants were asked to rate the statements on a 5-point Likert scale from strongly agree (5) to strongly disagree (1), as in the original TAM approach [24]. Before the respondents were asked to undertake the rating and were given instructions for the questionnaire, a TSS was described in general terms to give them an idea of the functionality and method of interaction with such a TSS system and service offering (see Additional File 2). At the end of the survey the respondents were asked for personal data.

Table 1 Results of operationalization: Construct definitions and scales of item dimensions

\section{Test of questionnaire and construct analysis}

The test period started in the second week of March and lasted for four weeks; it thus happened during the first weeks of the growing outbreak of the SarsCoV2 epidemic in Germany. The questionnaire was distributed online with the help of the market research institute Quopinion, which sent it to 62 volunteers from their database. SPSS (IBM Watson Studio Desktop \& SPSS Modeler and Statistics Version 26) was used for the statistical analysis of the items to evaluate all constructs. Cronbach's Alpha was measured to test the reliability of each construct and its internal consistency. The goal was to end up with between four and six items for each construct with an acceptable Cronbach's Alpha above 0.7. Items were eliminated to achieve a reliability improvement higher than 0.5 . In total, 40 datasets were included. The age distribution of the participants was between 21 and 63 , with an average age of 40 years. $35 \%$ of the participants were male, $63 \%$ were women and one participant answered other. Most of the respondents (75\%) worked in an employment relationship, with 22 working in a doctor's office, 17 in a clinic and one in another institution. The healthcare professionals worked in different medical disciplines: most in physiotherapy or psychology, and some in general medicine with a focus on nutrition/diabetes.

\section{Results}

Table 2 shows the reliability analysis of the constructs. All the constructs except STAN showed a high reliability after necessary amendments for COMP, FIN, REL, and TRU. After removing particular items, the total reliability shows a Cronbach's Alpha of 0.914 . As a consequence of the item revision analysis, the construct of the importance of standardization was removed, because the internal consistency was lower than 0.7 . A separate analysis for the more experienced participants (those aged above 30 years) also showed only a slightly higher reliability of 0.386 . 
Table 2

Reliability analysis after the test: Item elimination for Cronbach's Alpha amendment of each construct

\begin{tabular}{|c|c|c|c|c|c|}
\hline Construct & $\begin{array}{l}\text { Cronbach's Alpha of the construct } \\
\text { before item revision }\end{array}$ & Items eliminated & $\begin{array}{l}\text { Cronbach's Alpha of } \\
\text { the construct } \\
\text { after item revision }\end{array}$ & $\begin{array}{l}\text { Items } \\
\text { remaining }\end{array}$ & $\begin{array}{l}\text { Cronbach's Alpha of construct } \\
\text { if item were deleted }\end{array}$ \\
\hline \multirow[t]{4}{*}{ Attitude } & \multirow[t]{4}{*}{0.784} & \multirow[t]{4}{*}{ None } & \multirow[t]{4}{*}{0.784} & ATT1 & 0.682 \\
\hline & & & & ATT2 & 0.653 \\
\hline & & & & ATT3 & 0.757 \\
\hline & & & & ATT4 & 0.799 \\
\hline \multirow{4}{*}{$\begin{array}{l}\text { Behavioral } \\
\text { Intention }\end{array}$} & \multirow[t]{4}{*}{0.783} & \multirow[t]{4}{*}{ None } & \multirow[t]{4}{*}{0.783} & $\mathrm{Bl} 1$ & 0.704 \\
\hline & & & & $\mathrm{BI} 2$ & 0.648 \\
\hline & & & & $\mathrm{BI} 3$ & 0.836 \\
\hline & & & & $\mathrm{BI} 4$ & 0.685 \\
\hline \multirow{6}{*}{$\begin{array}{l}\text { Perceived } \\
\text { Usefulness }\end{array}$} & \multirow[t]{6}{*}{0.875} & \multirow[t]{6}{*}{ None } & \multirow[t]{6}{*}{0.875} & PU1 & 0.843 \\
\hline & & & & PU2 & 0.857 \\
\hline & & & & PU3 & 0.851 \\
\hline & & & & PU4 & 0.829 \\
\hline & & & & PU5 & 0.885 \\
\hline & & & & PU6 & 0.856 \\
\hline \multirow{5}{*}{$\begin{array}{l}\text { Perceived Ease of } \\
\text { Use }\end{array}$} & \multirow[t]{5}{*}{0.806} & \multirow[t]{5}{*}{ None } & \multirow[t]{5}{*}{0.806} & PEOU1 & 0.764 \\
\hline & & & & PEOU2 & 0.723 \\
\hline & & & & PEOU3 & 0.779 \\
\hline & & & & PEOU4 & 0.789 \\
\hline & & & & PEOU5 & 0.780 \\
\hline \multirow[t]{4}{*}{ Facilitators } & \multirow[t]{4}{*}{0.751} & \multirow[t]{4}{*}{ None } & \multirow[t]{4}{*}{0.751} & FAC1 & 0.852 \\
\hline & & & & FAC2 & 0.646 \\
\hline & & & & FAC3 & 0.661 \\
\hline & & & & FAC4 & 0.633 \\
\hline \multirow[t]{4}{*}{ Compatibility } & \multirow[t]{4}{*}{0.346} & \multirow[t]{4}{*}{ COMP5 removed } & \multirow[t]{4}{*}{0.751} & COMP1 & 0.771 \\
\hline & & & & COMP2 & 0.559 \\
\hline & & & & COMP3 & 0.666 \\
\hline & & & & COMP4 & 0.742 \\
\hline \multirow[t]{4}{*}{ Subjective Norms } & \multirow[t]{4}{*}{0.760} & \multirow[t]{4}{*}{ None } & 0.760 & SN1 & 0.756 \\
\hline & & & & SN2 & 0.627 \\
\hline & & & & SN3 & 0.736 \\
\hline & & & & SN4 & 0.687 \\
\hline Habit & 0.731 & None & 0.731 & HAB1 & 0.672 \\
\hline & & & & HAB2 & 0.655 \\
\hline & & & & HAB3 & 0.698 \\
\hline & & & & HAB4 & 0.633 \\
\hline & & & & HAB5 & 0.742 \\
\hline & & & & $\mathrm{HAB}$ & 0.735 \\
\hline $\begin{array}{l}\text { Importance of } \\
\text { Data Security }\end{array}$ & 0.713 & $\begin{array}{l}\text { IOD4 removed, as } \\
\text { improvement is }>0.5\end{array}$ & 0.763 & IOD1 & 0.637 \\
\hline
\end{tabular}




\begin{tabular}{|c|c|c|c|c|c|}
\hline Construct & $\begin{array}{l}\text { Cronbach's Alpha of the construct } \\
\text { before item revision }\end{array}$ & Items eliminated & $\begin{array}{l}\text { Cronbach's Alpha of } \\
\text { the construct } \\
\text { after item revision }\end{array}$ & $\begin{array}{l}\text { Items } \\
\text { remaining }\end{array}$ & $\begin{array}{l}\text { Cronbach's Alpha of construct } \\
\text { if item were deleted }\end{array}$ \\
\hline & & & & IOD2 & 0.667 \\
\hline & & & & IOD3 & 0.764 \\
\hline & & & & IOD5 & 0.761 \\
\hline \multirow[t]{5}{*}{ Financing } & \multirow[t]{5}{*}{0.466} & \multirow{5}{*}{$\begin{array}{l}\text { FIN5, FIN1, FIN4, FIN2 } \\
\text { removed }\end{array}$} & \multirow[t]{5}{*}{0.691} & FIN1 & 0.680 \\
\hline & & & & FIN2 & 0.637 \\
\hline & & & & FIN3 & 0.637 \\
\hline & & & & FIN4 & 0.603 \\
\hline & & & & FIN5 & 0.637 \\
\hline $\begin{array}{l}\text { Importance of } \\
\text { Standardization }\end{array}$ & 0.345 & $\begin{array}{l}\text { No improvement } \\
\text { possible }\end{array}$ & eliminated & $\begin{array}{l}\text { STAN 1- } \\
4\end{array}$ & none \\
\hline \multirow{5}{*}{$\begin{array}{l}\text { Relationship to } \\
\text { Patient }\end{array}$} & \multirow[t]{5}{*}{0.432} & \multirow{5}{*}{$\begin{array}{l}\text { REL1, REL2, REL3 } \\
\text { removed }\end{array}$} & \multirow[t]{5}{*}{0.729} & REL4 & 0.728 \\
\hline & & & & REL5 & 0.580 \\
\hline & & & & REL6 & 0.699 \\
\hline & & & & REL7 & 0.663 \\
\hline & & & & REL8 & 0.724 \\
\hline \multirow{4}{*}{$\begin{array}{l}\text { Trust in } \\
\text { Telemedicine } \\
\text { Center }\end{array}$} & \multirow[t]{4}{*}{0.565} & TRU3, TRU2, TRU1 & \multirow[t]{4}{*}{0.700} & TRU4 & 0.516 \\
\hline & & removed & & TRU5 & 0.666 \\
\hline & & & & TRU6 & 0.650 \\
\hline & & & & TRU7 & 0.696 \\
\hline
\end{tabular}

Table 2 Reliability analysis after the test: Item elimination for Cronbach's Alpha amendment of each construct

\section{Discussion}

The difficulty in the implementation of telemedicine is the consideration of the complexity of all mandatory settings. All the named burdens and drivers may influence the acceptance of this possible user group. Many studies have investigated patient acceptance [70], which seems insufficient on its own for this system interaction, as only a little is known about HCPs' acceptance. In this context, the treating healthcare professional is the initiator of the treatment and has the main responsibility for the medical care. Thus, it is critical to analyze the attitude of the treating HCP, who is the gatekeeper to the TSS [71]. Therefore, a glance at the technology acceptance research was needed to identify the relevant determinants for acceptance. The literature review shows the constructs of the external variables, covering the technical, organizational, social, legal, and individual context, that have been frequently supported, but only one study focused on the German healthcare market [40]. This made it necessary to adapt the constructs to the regional conditions in terms of the financial and legal aspects. Additionally, the literature review identified a gap in the consideration of the aspect of the interaction and cooperation with telemedicine centers and the active involvement of the patient, so that two new constructs, "trust in the telemedicine center" and "relationship to patient", were necessary to map out these structures. The test analysis confirmed the robust quality of ten acceptance constructs and a high reliability in total. Nevertheless, the proof of reliability needs to be replicated in further investigations and the variable STAN needs to be explored again. Several test participants mentioned in the free text option that the acceptance also depends on the opinion and ability of the patients. There needs to be an investigation into whether the attitude of the patients is also an important factor affecting the behavioral intention to use a TSS.

Since the focus on the healthcare professional and the required interactivity was missing from the literature, as was a German setting, this should be a special point in future research.

\section{Limitations}

There are several restrictions to the generalization of the findings. The literature review shows a high heterogeneity in studies of healthcare settings and disciplines regarding data analysis as well as the medical and regional focus. Nationwide studies focusing on single settings and areas need to be conducted to check on possible commonalities and differences. The review was limited to PubMed, so this research could only validate the reliability of the constructs for this selected variable set, but it drew a first picture of the relevant factors. Different data collection techniques and exploratory approaches to sharpen the factors are recommended. The new constructs have not yet been tested regarding their possible relationships with other variables and their significance for a TSS setting, and this requires exploratory factor analysis. 
Further, the test only included a limited set of treating HCPs, who might also have been influenced in their health area and profession by the Covid-19 situation, which made changes to communication with patients necessary.

The test described an example TSS which leads to a prognosis issue; subsequent research on the dynamic time measurement of technology acceptance is needed $[19,54]$.

\section{Conclusion}

Understanding the complexity of the factors influencing the acceptance by HCPs of the German telemonitoring market is crucial. This study developed a conceptual framework by identifying and designing multifaceted variables and operationalizing them in the validated questionnaire. This delivers a robust foundation that can be transferred into specific medical disciplines and professions in which telemonitoring systems with an involvement of telemedicine centers are considered. Furthermore, the factors of "relationship to patient" and "trust in telemedicine center" are a new basis for capturing the interaction of such TSS infrastructures. The adapted and new constructs were optimized through the testing and reached an acceptable reliability for further research. However, the results need to be combined with the attitudinal perspective of patients to pick up all relevant players in the system.

There is a great need for further research on German HCP acceptance in telemedicine, to provide evidence to identify the barriers and the potential, which will lead to a statement of the requirements of technology, legislation and financing of telemedicine structures in Germany for providers and policy, especially from the professional society view. This understanding is essential to develop the appropriate conditions for such complex programs and to close the existing gaps. Last but not least, the Covid-19 crisis and the first reaction to ease telehealth financing in Germany [72] shows the urgency and relevance of this topic.

\section{Abbreviations}

ATT

Attitude

BI

Behavioral Intention

COMP

Compatibility

DDG

Deutsche Diabetes Gesellschaft (German diabetes association)

DGP

Deutsche Gesellschaft für Pneumologie (German association of pneumology)

DGK

Deutschen Gesellschaft für Kardiologie (German association of cardiology)

FAC

Facilitators

$\mathrm{HAB}$

Habit

HCP

Healthcare professional

ICT

Information and communication technology

IT

Information technology

IOD

Importance of Data Security

PEOU

Perceived Ease of Use

PU

Perceived Usefulness

REL

Relationship to patient

SN

Subjective norms

TAM

Technology acceptance model

TRU

Trust in Telemedicine Center

TSS

Telemonitoring service system

UTAUT 
Unified Theory of Acceptance and Use of Technology

\section{Declarations}

Ethics approval and consent to participate

Not applicable.

Consent for publication

Not applicable.

Availability of data and materials

The datasets used and/or analyzed during the current study are available from the corresponding author on reasonable request.

\section{Competing interests}

The author declares that she has no competing interests.

\section{Funding}

No funding received.

\section{Authors' contributions}

This study is a research part of the PhD dissertation of the author, who wrote the paper on her own.

\section{Acknowledgements}

The author denies that there are any financial and personal relationships with other people or organizations that would inappropriately influence this work. No payments were received in relation to this work from consultancies, stock ownership, honoraria, paid expert testimony or patent applications.

The author offers thanks to the survey respondents and for the support of Quopinion.

\section{References}

1. A free English translation of all German article and book titles is given (in square brackets).

2. Chancen und Einsatzmöglichkeiten von Telemedizin in der HalsHagge D, Knopf A, Hofhauer B. Chancen und Einsatzmöglichkeiten von Telemedizin in der Hals-.

3. Nasen- und Ohrenheilkunde bei der Bekämpfung von SARS-COV-2. Narratives Review (Opportunities and possible applications of telemedicine in otorhinolaryngologic treatment in the fight against SARS-COV-2 Narratives Review). HNO. 2020;68:1-7. https://doi.org/10.1007/s00106-020-00864-7.

4. Boehm K, Ziewer S, Brandt MA, Sparwasser P, Haack M, Willems F, Thomas A, Dotzauer R, Höfner T, Tsaur I, Haferkamp A, Borgmann H. Telemedicine online visits in urology during the COVID-19 pandemic - Potential, risk factors, and patients' perspective. Eur Urol. 2020;78(1):16-20.

5. https://doi.org/10.1016/j.eururo.2020.04.055.

6. Driggin E, Madhavan MV, Bikdeli B, Chuich T, Laracy J, Biondi-Zoccai G, Brown TS, Der Nigoghossian C, Zidar DA, Haythe J, Brodie D, Beckman JA, Kirtan AJ, Stone GW, Krumholz HM, Parikh SA. Cardiovascular considerations for patients, health care workers, and health systems during the COVID-19 pandemic. J Am Coll Cardiol. 2020;75(18):2352-71. https://doi.org/10.1016/j.jacc.2020.03.031.

7. Philippi M. Digitalisierung als Wettbewerbsfaktor im Krankenhaus (Digitization as a competitive factor in hospitals). In: Meier PM, Düllings J, Henkel AG, Nolte G, editors. Digitale Transformation der Gesundheitswirtschaft (Digital Transformation of the Healthcare Economy). Stuttgart: Kohlhammer; 2019. pp. 128-34.

8. Zhu Y, Gu X, Xu C. Effectiveness of telemedicine systems for adults with heart failure: A meta-analysis of randomized controlled trials. Heart Fail Rev. 2020;25(2):231-43. https://doi.org/10.1007/s10741-019-09801-5.

9. Li X, Xie Y, Zhao H, Zhang H, Yu X, Li J. Telemonitoring interventions in COPD patients: Overview of systematic reviews. Biomed Res Int. 2020 ;e5040521. https://doi.org/10.1155/2020/5040521.

10. Bundesministerium für Wirtschaft und Energie. Jahresbericht der Bundesregierung zum Stand der Deutschen Einheit 2018 (Annual Report of the Federal Government on the State of German Unity 2018). 2018; https://www.bmwi.de/Redaktion/DE/Publikationen/Neue-Laender/jahresbericht-zum-stand-derdeutschen-einheit-2018.pdf?_blob=publicationFile\&v=14. Accessed 15 May 2020.

11. OECD/EU. Organisation for Economic Co-operation and Development/European Union. Health at a glance: Europe 2018: State of health in the EU cycle.2018. OECD Publishing. https://doiorg/101787/health_glance_eur-2018-en, Accessed 15 May 2020.

Page $12 / 16$ 
12. Digitale-Versorgung-Gesetz DVG. Gesetz für eine bessere Versorgung durch Digitalisierung und Innovation (Law for better healthcare by means of digitization and innovation) 9th December 2019. 2019; https://www.bgbl.de/xaver/bgbl/start.xav?

startbk=Bundesanzeiger_BGBI\&start=//*\%5B@attr_id=\%27bgbl119s2562.pdf\%27\%5D, Accessed 15 May 2020.

13. E-Health-Gesetz. Gesetz für sichere digitale Kommunikation und Anwendungen im Gesundheitswesen sowie zur Änderung weiterer Gesetze (Law for secure digital communication and applications in the healthcare sector and for the amendment of other laws). 2015; BGB. I p 2408 https://www.bgbl.de/xaver/bgbl/start.xav?start=\%2F\%2F*\%5B\%40attr_id\%3D\%27bgbl115s2408.pdf\%27\%5D, Accessed 15 May 2020.

14. Bundesministerium für Gesundheit. DiGAV Bundesministerium für Gesundheit. DiGAV. Digitale-Gesundheitsanwendungen-Verordnung. 2020. Verordnung über das Verfahren und die Anforderungen der Prüfung der Erstattungsfähigkeit digitaler Gesundheitsanwendungen in der gesetzlichen Krankenversicherung (Regulation on the process and requirements for testing the eligibility of digital health applications for reimbursement by the statutory health insurance). legal draft. 2020; https://www.bundesgesundheitsministerium.de/fileadmin/Dateien/3_Downloads/Gesetze_und_Verordnungen/GuV/D/DiGAV_RefE.pdf. Accessed 11 May 2020.

15. Bundesministerium für Gesundheit. PDSG. Gesetz zum Schutz elektronischer Patientendaten 2020 (Electronic Patient Data Protection Act 2020). legal draft. 2020;

https://www.bundesgesundheitsministerium.de/fileadmin/Dateien/3_Downloads/Gesetze_und_Verordnungen/GuV/P/Referentenentwurf_PatientendatenSchutzgesetz_PDSG.pdf. Accessed 11 May 2020.

16. Bundesärztekammer. Stellungnahme der Bundesärztekammer zum Referentenentwurf des Bundesministeriums für Gesundheit eines Gesetzes für eine bessere Versorgung durch Digitalisierung und Innovation. (Statement of the Federal Chamber of Physicians on the draft of the Federal Ministry of Health for a law for better healthcare by means of digitization and innovation.) 2019.

17. https://. Accessed 15 May 2020.

18. $10.1007 / \mathrm{s} 12181-013-0496-1$

Müller A, Rybak K, Klingenheben T, Schumacher B, Israel C, Helms TM, Oeff M, Perings S, Sack S, Piorkowski C, Preissler R, Zugck C, Schwab JO. (2013) Empfehlungen zum Telemonitoring bei Patienten mit implantierten Herzschrittmachern, Defibrillatoren und kardialen Resynchronisationssystemen (Recommendations for telemonitoring of patients with implanted pacemakers, defibrillators and cardiac resynchronization systems). Kardiologe 2013; 7:181-193. https://doi.org/10.1007/s12181-013-0496-1.

19. World Health Organization. Telemedicine: Opportunities and developments in Member States: Report on the second global survey on eHealth 2009, Global Observatory for eHealth Series 2. WHO Library Cataloguing-in-Publication Data. 2020;

https://apps.who.int/iris/bitstream/handle/10665/44497/9789241564144_eng.pdf?sequence=1\&isAllowed=y, Accessed 13 May 2020.

20. Kommission der Europäischen Gemeinschaften. Mitteilung der Kommission an das europäische Parlament, den Rat, den europäischen Wirtschafts- und Sozialausschuss und den Ausschuss der Regionen über den Nutzen der Telemedizin für Patienten, Gesundheitssysteme und die Gesellschaft (Communication from the Commission to the European Parliament, the Council, the European Economic and Social Committee and the Committee of the Regions on the benefits of telemedicine for patients, healthcare systems and society). 2008; https://ec.europa.eu/transparency/regdoc/rep/1/2008/DE/12008-689-DE-F1-1.Pdf Accessed 12 May 2020.

21. Ihlenburg D. Interaktionsplattformen und Kundenintegration in Industriegütermärkten (Interaction platforms and customer integration in markets for industrial goods). Wiesbaden: Gabler; 2012.

22. Yarbrough AK, Todd BS. Technology acceptance among physicians: A new take on TAM, an interface-driven analysis of user interactions with an electronic health record system. Med Care Res Rev. 2007;64(6):650-72. https://doi.org/10.1177/1077558707305942.

23. Kollmann T. Akzeptanz innovativer Nutzungsgüter und -systeme (Acceptance of innovative utility goods and systems). Wiesbaden: Springer; 1998.

24. Müller-Böling D, Müller M. Akzeptanz der Bürokommunikation (Acceptance of Office Communications). München: R. Oldenbourg; 1986.

25. Simon B. E-Learning an Hochschulen - Gestaltungsräume und Erfolgsfaktoren von Wissensmedien (E-Learning at universities - design spaces and success factors of knowledge media). Lohmar: Jospeh Eul Verlag; 2001.

26. Kroeber-Riel W, Gröppel-Klein A. Konsumentenverhalten (Consumer behavior). 10th ed. München: Vahlen; 2013.

27. Jockisch M Das Technologieakzeptanzmodell (The technology acceptance model). In: Bandow G, Holzmüller G, Hartmut H, editors. "Das ist gar kein Modell!" - Unterschiedliche Modelle und Modellierungen in Betriebswirtschaftslehre und Ingenieurwissenschaften ("This is not a model at all!" - Different models and modelling in business administration and engineering). Wiesbaden: Gabler; 2010. p. 233-254.

28. Davis FD. Perceived usefulness, perceived ease of use, and user acceptance of information technologies. MIS Q. 1989;13(3):319-40. https://doi.org/10.2307/249008.

29. Momani AM, Jamous MM. The evolution of technology acceptance theories. Int J of Comtemp Res. 2017;1(1):51-8. http://ojs.mediu.edu.my/index.php/IJCCR/article/view/479/296.

30. Holden RJ, Karsh B-T. The Technology Acceptance Model: Its past and its future in health care. J of Biomed Inform. 2010;43(1):159-72. https://doi.org/10.1016/j.jbi.2009.07.002.

31. Venkatesh V, Davis FD. A theoretical extension of the technology acceptance model: Four longitudinal field studies. Manag Sci. 2000;46(2):186-204. https://www.jstor.org/stable/2634758.

32. Venkatesh V, Morris MG, Davis GB, Davis FD. Technology: toward a unified view. MIS Q. 2003;27(3):425-78. https://www.jstor.org/stable/30036540.

33. Taylor S, Todd P. Assessing. IT usage: A test of competing models. Inform Syst Res. 1995;6(2):144-76. . 
34. Lee Y, Kozar KA, Larsen KRT. The technology acceptance model: Past, present, and future. Commun AIS. 2003;12(1):752-80.

https://doi.org/10.17705/1CAIS.01250.

35. King WR, He J. A meta-analysis of the technology acceptance model. Inf Manag. 2006;43(6):740-55. https://doi.org/10.1016/j.im.2006.05.003.

36. Mezni H, Gagnon M, Desmartis M, Duplantie J. A systematic mixed method review of theories of telehealth adoption. Paper presented at the Canadian Society of Telehealth Conference, Ottawa, Ontario; 2003.

37. Yang HD, Yoo Y. It's all about attitude: Revisiting the technology acceptance model. Decis Support Syst. 2004;38(1):19-31. https://doi.org/10.1016/S0167-9236(03)00062-9.

38. Monthuy-Blanc J, Bouchard S, Maïano C, Séguin M. Factors influencing mental health providers' intention to use telepsychotherapy in First Nations communities. Transcult Psychiatry. 2013;50(2):323-43. https://doi.org/10.1177/1363461513487665.

39. Hersh WR, Helfand M, Wallace J. Clinical outcomes resulting from telemedicine interventions: A systematic review. BMC Med Inform Decis Mak 2001;1(5). https://doi.org/10.1186/1472-6947-1-5.

40. Finkelstein SM, Speedie SM, Zhou X, Potthoff S, Rahter ER. Perception, satisfaction and utilization of the value home tele-health services. J Telemed Telecare. 2011;17(6):288-92. https://doi.org/10.1258/jtt.2011.100712.

41. Moher D, Liberati A, Tetzlaff J, Altman DG, The PRISMA Group. Preferred Reporting Items for Systematic Reviews and Meta-Analyses: The PRISMA Statement. PLoS Med. 2009;6(7):e1000097. https://doi.org/10.1371/journal.pmed.1000097.

42. Kayode IA, Noorminshah Al, Miskon S. Towards reinforcing telemedicine adoption amongst clinicians in Nigeria. Int J Med Inform. 2017;104:84-96. https://doi.org/10.1016/j.jimedinf.2017.05.008.

43. Rho MJ, Choi I, Lee J. Predictive factors of telemedicine service acceptance and behavioral intention of physicians. Int J Med Inform. $2014 ; 83(8): 559-71$. https://doi.org/10.1016/j.jimedinf.2014.05.005.

44. Dünnebeil S, Sunyaev A, Blohm I, Leimeister JM, Krcmar H. Determinants of physicians' technology acceptance for e-health in ambulatory care. Int J Med Inform. 2012;81(11):746-60. https://doi.org/10.1016/j.ijmedinf.2012.02.002.

45. Gagnon MP, Godin G, Gagné C, Fortin J-P, Cloutier A. An adaptation of the theory of interpersonal behaviour to the study of telemedicine adoption by physician. Int J Med Inform. 2003;71(2-3):103-15. https://doi.org/10.1016/S1386-5056(03)00094-7.

46. Hwang JY, Kim KY, Lee KH. Factors that influence the acceptance of telemetry by emergency medical technicians in ambulances: An application of the extended technology acceptance model. Telemed J E Health. 2014;20(12):1127-34. https://doi.org/10.1089/tmj.2013.0345.

47. Saigí-Rubió F, Torrent-Sellens J, Jiménez-Zarco A. Drivers of telemedicine use: Comparative evidence from samples of Spanish, Colombian and Bolivian physicians. Implement Sci. 2014;9(128). https://doi.org/10.1186/s13012-014-0128-6.

48. Okazaki S, Castañeda JA, Sanz S. Clinicians' assessment of mobile monitoring: A comparative study in Japan and Spain. Medicine 20. 2013 ;2(2):e11. https://doi.org/10.2196/med20.2874.

49. Gagnon MP, Orruño E, Asua J, Abdeljelil AB, Emparanza J. Using a modified technology acceptance model to evaluate healthcare professionals' adoption of a new telemonitoring system. Telemed J E Health. 2012;18(1):54-9. https://doi.org/10.1089/tmj.2011.0066.

50. Saigí-Rubió F, Jiménez-Zarco A, Torrent-Sellens J. Determinants of the intention to use telemedicine: Evidence from primary care physicians. Int J Technol Assess Health Care. 2016;32(1/2):29-36. https://doi.org/10.1017/S0266462316000015.

51. Stratton D, Loescher LJ. The acceptance of mobile teledermoscopy by primary care nurse practitioners in the state of Arizona. J Am Assoc Nurse Pract. 2016;28(6):287-93. https://doi.org/10.1002/2327-6924.12313.

52. Orruño E, Gagnon MP, Asua J, Ben Abdeljelil A. Evaluation of teledermatology adoption by health-care professionals using a modified Technology Acceptance Model. J Telemed Telecare. 2011;17(6):303-7. https://doi.org/10.1258/jtt.2011.101101.

53. Asua J, Orruño E, Reviriego E, Gagnon MP. Healthcare professional acceptance of telemonitoring for chronic care patients in primary care. BMC Med Inform Decis Mak. 2012; 12(139). https://doi.org/10.1186/1472-6947-12-139.

54. James S, Perry L, Gallagher R, Lowe J. Diabetes Educators' Intended and Reported Use of Common Diabetes-Related Technologies: Discrepancies and Dissonance. J of Diabetes Sci Technol. 2016;10(6):1277-86. https://doi.org/10.1177/1932296816646798.

55. Oyetunde 00, Ogidan O, Akinyemi MI, Ogunbameru AA, Asaolu OF. Mobile authentication service in Nigeria: An assessment of community pharmacists' acceptance and providers' views of successes and challenges of deployment. Pharm Prac (Granada). 2019;17(2):1449. https://doi.org/10.18549/PharmPract.2019.2.1449.

56. Kissi J, Dai B, Dogbe SC, Banahene J, Ernest O. Predictive factors of physicians' satisfaction with telemedicine services acceptance. Health Informat J. 2019;26(3):1866-80. https://doi.org/10.1177/1460458219892162.

57. Bagot K, Moloczij N, Arthurson L, Hair C, Hancock S, Bladin CF, Cadilhac DA. Nurses' role in implementing and sustaining acute telemedicine: A mixedmethods, pre-post design using an extended technology acceptance model. J of Nurs Scholarsh. 2019;52(1):34-46. https://doi.org/10.1111/jnu.12509.

58. Pereyra-Rodriguez JJ, Jiménez-Zarco Al, Saigí-Rubió F. Factors that determine the intention to use telemedicine in a healthcare organisation. J of Healthc Qual Res. 2018;33(6):319-28. https://doi.org/10.1016/j.jhqr.2018.08.004.

59. Broens T, Huis in't Veld R, Voellenbroeck-Hutten M, Hermens HJ, van Halteren A, Nieuwenhuis L. Determinants of successful telemedicine implementation: A literature study. J Telemed Telecare. 2007;13(6):303-9. https://doi.org/10.1258/135763307781644951.

60. Statistisches Bundesamt. Statistisches Jahrbuch 2019, 4 Gesundheit (Statistical Yearbook 2019, 4 Healthcare). 2019; https://www.destatis.de/DE/Themen/Querschnitt/Jahrbuch/jb-gesundheit.pdf?_blob=publicationFile, Accessed 12 May 2020.

61. Robert-Koch Institut RKI. Gesundheitsbericht. Gesundheitsberichterstattung Des Bundes gemeinsam getragen von RKI Und Destatis Gesundheit in Deutschland (Health report. Federal Health Reporting Supported by RKI and Destatis Health in Germany). 2015; http://www.gbe-

Page $14 / 16$ 
bund.de/pdf/GESBER2015.pdf, Accessed 15 May 2020.

62. Ickarth M. Bedeutung der Digitalisierung für die DDG als Fachgesellschaft (Importance of digitization for the DDG as a medical association). Diabetologe. 2018;14:449-54. https://doi.org/10.1007/s11428-018-0390-3.

63. Randerath W, Bögel N, Franke C, Hellmann A, Jany B, Nilius G, Penzel T, Voshaar T, Wiater A. Positionspapier zum Telemonitoring bei schlafbezogenen Atmungsstörungen (Position paper on telemonitoring. Sleep-related breathing disorders). Pneumologie. 2017;71:81-5. http://dx.doi.org/10.1055/s-0042124083.

64. Zippel-Schultz B, Schultz C. Current status and future of telemonitoring: Scenarios for telemedical care in 2025. Herzschr Elektrophys. 2017;28(3):245-56. https://doi.org/10.1007/s00399-017-0520-4.

65. Leppert F, Dockweiler C, Eggers N, Webel K, Hornberg C, Greiner W. Financial conditions as influencing factors for telemonitoring acceptance by healthcare professionals in Germany. J Int Soc for Telemed eHealth. 2015;3: e13(1) -e13(9). https://pub.uni-bielefeld.de/record/2732002.

66. Osman MA, Schick-Makaroff K, Thompson S, Bialy L, Featherstone R, Kurzawa J, Zaidi D, Okpechi I, Habib S, Shojai S, Jindal K, Braam B, Keely E, Liddy C, Manns B, Tonelli M, Hemmelgarn B, Klarenbach S, Bello AK. Barriers and facilitators for implementation of electronic consultations (eConsult) to enhance access to specialist care: A scoping review. BMJ Glob Health. 2019;4(5):e001629. https://doi.org/10.1136/bmjgh-2019-001629.

67. Lee MS, Ray KN, Mehrotra A, Giboney P, Yee FE, Barnett ML. Primary care practitioners' perceptions of electronic consult systems. A qualitative analysis. JAMA Intern Med. 2018;178(6):782-9. https://doi.org/10.1001/jamainternmed.2018.0738.

68. Felício JA, Couto E, Caiado J. Human capital and social capital in entrepreneurs and managers of small and medium enterprises. J Bus Econ Manag. 2012;13(3):395-420. https://doi.org/10.3846/16111699.2011.620139.

69. Mohseni M, Lindstrom M. Social capital, trust in the health-care system and self-rated health: The role of access to health care in a population-based study. Soc Sci Med. 2007;64(7):1373-83. https://doi.org/10.1016/j.socscimed.2006.11.023.

70. Schweer M, Thies B. Vertrauen als Organisationsprinzip(Trust as an organizational principle). Bern: Hans Huber; 2003.

71. Yamagashi T, Yamagashi M. Trust and commitment in the United States and Japan. Motiv Emot. 1994;18:129-66. https://doi.org/10.1007/BF02249397.

72. Möhring W, Schlütz D. Die Befragung in der Medien- und Kommunikationswissenschaft (Surveys in media and communication science). 2nd ed. Wiesbaden: Springer; 2010.

73. Olbrecht T. Akzeptanz von E-Learning. Eine Auseinandersetzung mit dem Technologieakzeptanzmodell zur Analyse individueller und sozialer Einflussfaktoren (Acceptance of E-Learning. An assessment of the technology acceptance model for the analysis of individual and social influencing factors). Dissertation. University of Jena, Germany; 2010.

74. Harst L, Lantzsch H, Scheibe M. Theories predicting end-user acceptance of telemedicine use: Systematic review. J Med Internet Res. $2019 ; 21(5): e 13117$. https://doi.org/10.2196/13117.

75. Brewster L, Mountain G, Wessels B, Kelly C, Hawley M. Factors affecting front line staff acceptance of telehealth technologies: A mixed-method systematic review. J of Adv Nurs. 2013;70(1):21-33. https://doi.org/10.1111/jan.12196.

76. Kassenärztliche Bundesvereinigung. Coronavirus: Videosprechstunden unbegrenzt möglich. (Coronavirus: Video consultations are possible without restrictions) Praxisnachrichten. 2020; https://wwwkbvde/html/1150_44943php. Accessed 15 May 2020.

77. Fishbein M, Ajzen I. Belief, attitude, intention and behavior: An introduction to theory and research. Reading: Addison-Wesley; 1975.

78. Venkatesh V, Bala H. Technology Acceptance Model 3 and a research agenda on interventions. Dec Sci. 2008;39(2):273-315. https://doi.org/10.1111/j.1540-5915.2008.00192.x.

79. Davis FD, Bagozzi RP, Warshaw PR. User acceptance of computer technology: a comparison of 2 theoretical models. Manag Sci. 1989;35(8):982-1003. https://doi.org/10.287/mnsc.35.8.982.

80. Rogers EM. Diffusion of innovations. 5th ed. New York: Simon and Schuster; 2003.

81. Additional file 1 Text. Introductory text for the questionnaire, in English.

82. Additional file 2 Table. German translation of the items used in the questionnaire for the field test.

\section{Figures}



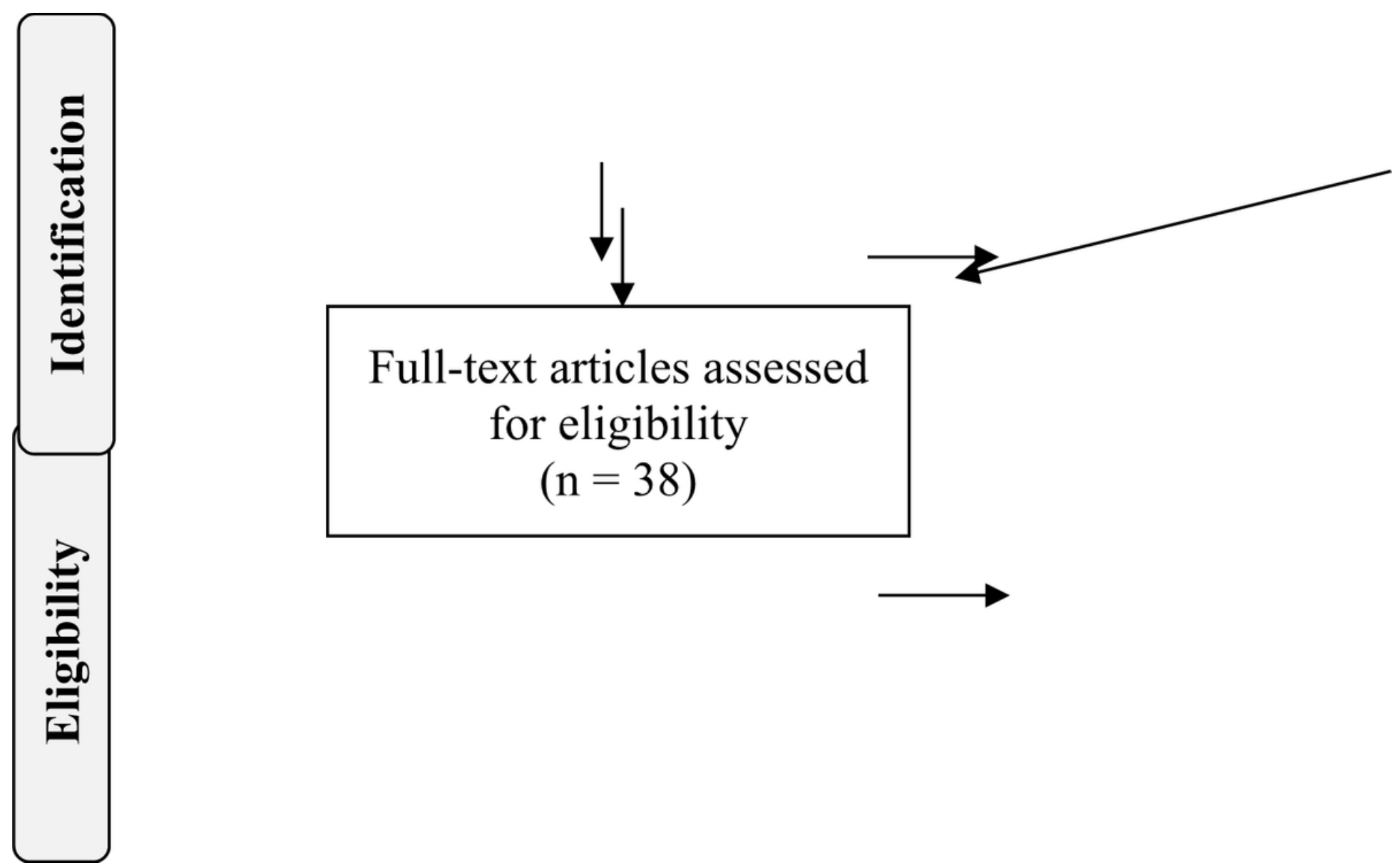

Figure 1

Flow chart to show the selection criteria used in the systematic literature review

\section{Supplementary Files}

This is a list of supplementary files associated with this preprint. Click to download.

- SupplementaryMaterial2Table.docx

- SupplementaryMaterial1Text.docx 